\title{
Segregation of migrating reacted melts through the ultraslow- spreading lower oceanic crust
}

\author{
LYDÉRIC FRANCE ${ }^{1 *}$, CARLOTTA FERRANDO ${ }^{1,2}$, \\ VALENTIN BASCH $^{2}$, ALESSIO SANFILIPPO ${ }^{2}$, MARINE \\ BOULANGER $^{1}$, RICCARDO TRIBUZIO ${ }^{2}$, ETIENNE \\ DELOULE $^{1}$ \\ ${ }^{1}$ CRPG-CNRS, Université de Lorraine, Nancy, France \\ * correspondence: lyderic.france@univ-lorraine.fr \\ ${ }^{2}$ Dip. Scienze della Terra e dell'Ambiente, Uni. Pavia, Italy
}

Slow- to ultraslow- spreading oceanic crust is constructed by a complex history of multiple magma injections, which react with the pre-existing crystal-matrix through a reactive porous flow process. This process have a profound effect on the composition of erupted MORBs. The process responsible for MORB ( reacted melts) seggregation from a crystal mush remains nevertheless totally unknown. To better understand (i) melt migration through the lower oceanic crust and (ii) the mechanisms of melt seggregation and supply to the overlying MORBs, we investigate the $810 \mathrm{~m}$ long plutonic section (mainly formed of olivine gabbro) of the Atlantis Bank Oceanic Core Complex (SWIR, $57^{\circ} \mathrm{E}$; IODP Hole U1473A).

U1473A olivine gabbros display intense grain size variability throughout the Hole from fine- (FG) to coarsegrained $(\mathrm{CG})$ with commonly irregular contacts (one contact every $4 \mathrm{~m}$ ). At contacts, resorbed grain boundaries of CG plagioclase $[\mathrm{Pl}]$ and clinopyroxene $[\mathrm{Cpx}]$ against the $\mathrm{FG}$ olivine gabbros suggest partial dissolution by a melt that crystallized the FG material. Mineral compositions record a progressive chemical evolution from more primitive cores of CG minerals to more evolved compositions of their relative rims, the latter being similar to the FG minerals. Significant enrichments in the most incompatible elements are widespread at rims of CG Pl and Cpx and in FG minerals, thus highlighting that magma differentiation is associated with melt-mineral interactions at all depths in the crystalmush. Products of such reactions are Ol, $\mathrm{Pl}$ and $\mathrm{Cpx}$.

Overall, downhole compositions of $\mathrm{Pl}$ are homogeneous and preserve those of the pre-existing $\mathrm{Ol}+\mathrm{Pl}$ crystal-mush. Conversely, Cpx compositions define upward chemical differentiation trends that record porous melt migration occurring at relatively high temperatures. As temperature decreases, reacted melts are segregated at different depths forming the small magma pockets that ultimately crystallize to form the FG intervals. Finally we document here for the first time, clear evidences of reacted melt seggregation within the plutonic section of oceanic ridges, a process that have the potential to collect reacted melts to feed MORBs. 